\title{
31. DIAGENESIS OF BASAL SEDIMENTS AND BASALTS OF SITES 322 AND 323, LEG 35, BELLINGSHAUSEN ABYSSAL PLAIN
}

\author{
Miriam Kastner, Scripps Institution of Oceanography, La Jolla, California
}

\begin{abstract}
Basal sediments, basalts, and porcelanites at Sites 322 and 323, Leg 35, Bellingshausen Abyssal Plain, were studied by a petrographic microscope, X-ray diffraction, electron microprobe, and scanning electron microscope with an X-ray energy-dispersive attachment. Volcanic contribution to the lowermost few meters of the basal sediments is greater at Site 322 than at Site 323. The main diagenetic phase of the basal sediments at Site 322 is smectite. The main diagenetic phases at Site 323 are smectite with $\mathrm{Fe} / \mathrm{Al}$ ratio of about 0.5 and clinoptilolite with $\mathrm{Si} / \mathrm{Al}$ ratio of about 4.7. Amorphous material, smectite with $\mathrm{Fe} / \mathrm{Al}$ ratio of about 1.7, and phillipsite with $\mathrm{Si} / \mathrm{Al}$ ratio of about 2.6 are the diagenetic products of basalt weathering at Site 322 . Instead, at Site 323 veins of celadonite, goethite, and calcite with $0.73 \% \mathrm{Mn}$ predominate. A possible hydrothermal origin is suggested for the Site 323 assemblage. The chemistry of smectites reflects the composition of their precursor(s).

Dissolution of biogenic silica contributed most of the silica for the porcelanite beds at $400-460$ meters, Site 323. Small amounts of authigenic K-feldspar were identified in one of the porcelanite beds.
\end{abstract}

\section{INTRODUCTION}

Diagenetic processes of basal sediments and altered basalts from Sites 322 and 323 and their relation to observed oxygen isotope and chemical variations of the sediments, basalts, and pore waters are emphasized.

Weathering of volcanic material in the sediment column or of oceanic basement basalt has been suggested as the source for the observed oxygen isotope and chemical (in particular calcium and magnesium) gradients in interstitial waters (Lawrence et al., 1975). During Leg 35, only two sites, 322 and 323 , were drilled to ocean basement, ${ }^{1}$ and therefore were chosen for this study.

Interstitial water analyses of Site 323 show similar, but much more distinct, oxygen isotope, $\mathrm{Ca}^{+2}, \mathrm{Mg}^{+2}$, and $\mathrm{K}^{+}$gradients than those of Site 322 (Gieskes and Lawrence, this volume). Indeed, basalt at Site 323 is more extensively weathered than that at Site 322 , and the weathering products are also different. Amorphous or colloidal material, smectite, and phillipsite are the weathering products of Site 322 basalt. No amorphous or colloidal material was observed in the basalt at Site 323 , and the main weathering products are saponite, celadonite, goethite, and calcite.

The relatively sharp change in the slopes of the $\mathrm{Ca}^{+2}$, $\mathrm{Mg}^{+2}$, and silica concentration gradients in the interstitial waters of Site 323, at 400-500 meters (Gieskes and Lawrence, this volume), can be well correlated with porcelanite and smectite formation at this interval.

\footnotetext{
'Basalt at Site 323 is probably a sill or sills, but seismic data suggest that it is close to true ocean basement (Vennum, this volume).
}

\section{SITE DESCRIPTION}

Water depths at Sites 322 and 323 are 5026 and 4993 meters, respectively. Both sites were below the carbonate compensation depth (CCD) during most of their sedimentary history. Terrigenous sediments predominate in the upper portions of both sites. The lower parts of the sections show a higher contribution of volcanic material (Drever and Perry, this volume). However, based on $\mathrm{Ti} / \mathrm{Al}$ ratios of bulk sediments, Donnelly (this volume) suggests that terrigenous material predominates throughout the sections. Sediments younger than Miocene have higher sedimentation rates than older sediments. In general, the average sedimentation rate is higher at Site 322 ( 5 to $3 \mathrm{~cm} / 1000$ yr) than at Site 323 (4 to $1.5 \mathrm{~cm} / 1000 \mathrm{yr}$ ).

Basement basalt at Site 322 was reached at 544 meters depth and is of much younger age than basement basalt at Site 323, which is at least of Maestrichtian age (Tucholke and Houtz, this volume). It was reached at 701 meters.

\section{EXPERIMENTAL METHODS}

Smear slides of all samples were examined with the petrographic microscope.

Basal sediments: Each sample was dispersed in distilled water and the $<2 \mu \mathrm{m}$ fraction separated by centrifugation. The $<2 \mu \mathrm{m}$ and $>2 \mu \mathrm{m}$ fractions were analyzed by X-ray diffraction, following Drever's (1973) technique for the clay fraction.

Clay minerals data are presented in Tables 1A, 1B, and 2 as relative peak intensities and not relative clay abundances, which are unreliable (Towe, 1974). The following peaks were used: $10 \AA$ for illite, $7 \AA$ for chlorite (kaolinite is either absent or present in negligible 
TABLE 1A

Mineralogy of Basal Sediments and Altered Basalt, Site 322

\begin{tabular}{|c|c|c|c|c|}
\hline \multirow[b]{2}{*}{$\begin{array}{l}\text { Sample } \\
\text { (Interval in } \mathrm{cm} \text { ) }\end{array}$} & \multirow{2}{*}{$\begin{array}{l}\text { Depth } \\
\text { in Core } \\
(\mathrm{m})\end{array}$} & \multicolumn{2}{|c|}{ X-Ray Diffraction } & \multirow[b]{2}{*}{ Additional Observations } \\
\hline & & $\begin{array}{c}<2 \mu \mathrm{m} \text { Fraction } \\
\mathrm{Q}: \mathrm{I} / \mathrm{S}: \mathrm{I}\end{array}$ & $\begin{array}{c}>2 \mu \mathrm{m} \text { Fraction } \\
\mathrm{Q}: \mathrm{P}\end{array}$ & \\
\hline \multicolumn{5}{|l|}{ Basal Sediments } \\
\hline $11-5,18-20$ & 510.7 & $0.5: 9.0: 0.5$ & $2.5: 7.5$ & $\begin{array}{l}\text { In all basal sediment samples; } \\
\text { relatively fresh, colorless (siliceous); } \\
\text { volcanic glass is present }\end{array}$ \\
\hline $11-5,67-69$ & 511.2 & $1.0: 7.5: 1.5$ & $2.5: 7.5$ & \\
\hline $11-5,110-112$ & 511.5 & $0.5: 6.0: 3.5$ & $3.5: 6.5$ & \\
\hline $11-6,30-32$ & 512.3 & $1.0: 7.0: 2.0$ & $4.0: 6.0$ & \\
\hline $11-6,103-105$ & 513.0 & $1.0: 5.0: 4.0$ & $5.0: 5.0$ & \\
\hline $11, \mathrm{CC}$ & 513.5 & $0.5: 2.5: 7.0$ & $5.0: 5.0$ & \\
\hline \multicolumn{5}{|l|}{ Altered Basalt } \\
\hline $12-1,93-94$ & 514.4 & $\begin{array}{l}\text { Mainly plagioclase, } \\
\text { small amounts of } \\
\text { smectite }\end{array}$ & $\begin{array}{l}\text { Mainly } \\
\text { plagioclase }\end{array}$ & $\begin{array}{l}\text { Light brown volcanic glass partially } \\
\text { altered, some amorphous material }\end{array}$ \\
\hline $12-1,147-149$ & 515.0 & $\begin{array}{l}\text { No detectable } \\
\text { peaks }\end{array}$ & $\begin{array}{l}\text { No detectable } \\
\text { peaks }\end{array}$ & $\begin{array}{l}\text { Abundant light brown volcanic glass; } \\
\text { many are partially or completely } \\
\text { altered }\end{array}$ \\
\hline $13-1,25-26$ & 532.8 & Only smectite & $\begin{array}{l}\mathrm{I} / \mathrm{S} \text { in } \\
\text { phillipsite }= \\
6.5: 3.5\end{array}$ & $\begin{array}{l}\text { Fe-rich smectite inclusions in } \\
\text { euhedral phillipsite crystals }\end{array}$ \\
\hline $13-1,73-77$ & 533.2 & $\begin{array}{l}\text { Mainly plagioclase, } \\
\text { small amounts of } \\
\text { smectite }\end{array}$ & $\begin{array}{l}\text { Mainly } \\
\text { plagioclase } \\
\text { and pyroxene }\end{array}$ & $\begin{array}{l}\text { Light brown volcanic glass, partially } \\
\text { altered; some amorphous material }\end{array}$ \\
\hline
\end{tabular}

Note: $\mathrm{Q}=$ Quartz, $3.34 \AA ; \mathrm{I} / \mathrm{S}=$ Illite/smectite, $17 \AA ; \mathrm{I}=$ Illite, $10 \AA ; \mathrm{P}=$ Plagioclase, $3.16-3.21 \AA$.

amounts), and $17 \AA$ for mixed-layered illite/smectite. Percent smectite layers in mixed-layered illite/smectite were determined by considering the $17 \AA$ peak intensity and the ratio of low angle to high angle trough heights of that peak, whenever the $(002)_{10} \AA /(003)_{17} \AA$ peak was too weak.

Basalts: A portion of each sample was crushed and then treated as above. In addition, polished thin sections were analyzed with a petrographic microscope and individual minerals were analyzed with an Applied Research Laboratories EMX electron microprobe.

Porcelanite and siliceous clay samples from Site 323 at 409 to 465 meters (Table 2) were also analyzed with the electron microprobe for chemical and cathodeluminescence variations.

Individual and coexisting authigenic minerals were analyzed for major element ratios by an Ortec Delphi Xray energy-dispersive system excited at $20 \mathrm{kv}$ and mounted on a Cambridge S4 scanning electron microscope.

\section{RESULTS AND DISCUSSION}

\section{Site 322}

Unit 4, the deepest sedimentary unit, is described as brown claystone (site report, this volume). Six samples from the bottom 3.5 meters of this unit and four basalt samples were examined. The mineralogy of these samples is summarized in Table 1A.

A change from a predominantly volcanic assemblage of illite/smectite, with greater than $80 \%$ smectite layers, and plagioclase, 3.5 meters above the basalt, to a mainly terrigenous assemblage of abundant illite, plagioclase, and some chlorite and illite/smectite, with only $60 \%$ to $70 \%$ smectite layers at 1 meter above the basalt, is shown in Figure 1. Indeed the $\delta \mathrm{O}^{18}$ value of Sample 322-11, CC, just 0.5 meter above the basalt is $+16.8^{\circ} \%$ (Lawrence, this volume), a typical value for a well-mixed terrigenous sediment.

The aphanitic, variolitic, and glassy basalt with hyaloclastite and composition of mid-oceanic ridge tholeiite basalt (Vennum, this volume) is altered to either only amorphous material or to a similar amorphous material and iron-rich smectite, or smectite and phillipsite, as shown in Table 1A. The pyroxenes are strongly altered, the plagioclases only partially altered. $\mathrm{X}$-ray energy-dispersive analysis of the phillipsite and coexisting smectite gave the following results:

$$
\begin{array}{cc}
\text { Phillipsite } & \text { Smectite } \\
\mathrm{Si} / \mathrm{Al} \simeq 2.6 & \mathrm{Fe} / \mathrm{Al} \simeq 1.7 \\
\mathrm{~K}>>\mathrm{Na} & \mathrm{Fe}>\mathrm{Al}>>\mathrm{Mg}
\end{array}
$$

Similar $\mathrm{Si} / \mathrm{Al}$ ratios for Pacific Ocean phillipsites are given by Sheppard et al. (1970). The $\delta \mathrm{O}^{18}$ value of the iron-rich smectite is $+23.4^{\circ} \% 0$ (analyzed by J.R. Lawrence). This value suggests a temperature of about $20^{\circ} \mathrm{C}$ assuming equilibrium with water of $0 \%$. Allowing a temperature gradient of $6^{\circ} \mathrm{C} / 100$ meters, $20^{\circ} \mathrm{C}$ corresponds to burial depth of about 330 meters.

The above iron-rich smectite is also present as numerous inclusions in the euhedral phillipsite crystals of Sample 322-13-1, 25-26 cm. This observation and the SEM photomicrographs of Plate 1, strongly suggest that the formation of the iron-rich smectite preceded the for- 
TABLE 1B

Mineralogy of Basal Sediments and Altered Basalts, Site 323

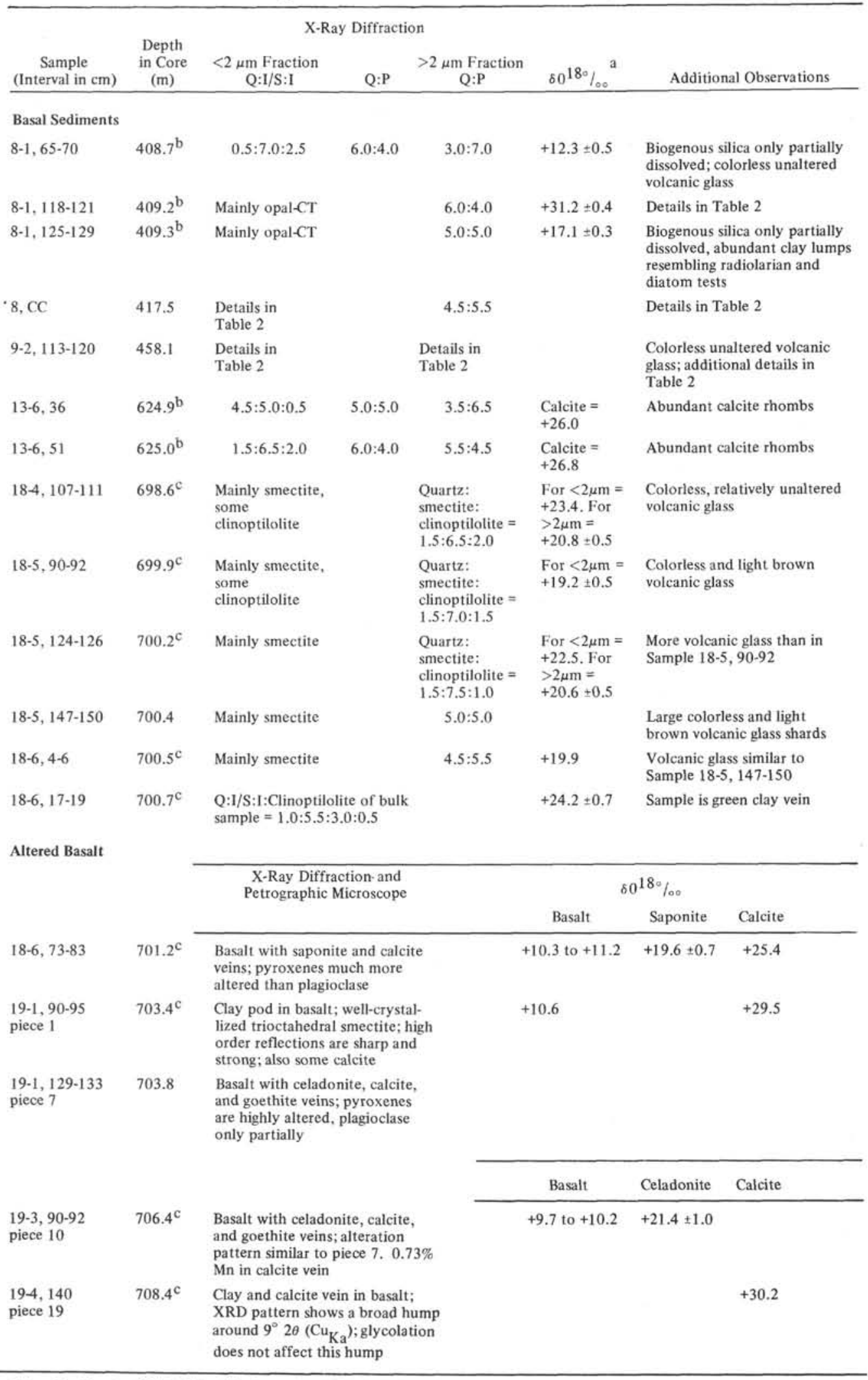

Note: $Q=$ Quartz, $3.34 \AA ; I / S=$ Illite $/$ smectite, $17 \AA ; I=$ Illite, $10 \AA ; P=$ Plagioclase, $3.16-3.21 \AA$.

${ }^{a}$ Relative to SMOW.

$\mathrm{b}_{\delta 0} 18$ by T. F. Anderson.

$\mathrm{c}_{\delta 0^{18}}$ by J. R. Lawrence. 
TABLE 2

Mineralogy and Oxygen Isotope Values of Porcelanite Beds from Site 323

\begin{tabular}{|c|c|c|c|c|c|c|c|c|}
\hline \multirow{2}{*}{$\begin{array}{c}\text { Sample } \\
\text { (Interval in } \mathrm{cm} \text { ) }\end{array}$} & \multirow{2}{*}{$\begin{array}{c}\text { Depth } \\
\text { (m) }\end{array}$} & \multirow[b]{2}{*}{$\%$ Clay } & \multirow{2}{*}{$\delta 0^{18} \%{ }^{\mathrm{a}}$} & \multirow{2}{*}{$\begin{array}{c}<2 \mu \mathrm{m} \\
\% \mathrm{~S} \text { in } \mathrm{S} / \mathrm{I}\end{array}$} & \multirow{2}{*}{$\begin{array}{l}<2 \mu \mathrm{m} \\
\mathrm{S}: \mathrm{I}\end{array}$} & \multirow{2}{*}{$\begin{array}{c}>2 \mu \mathrm{m} \\
\text { S:I }\end{array}$} & \multicolumn{2}{|c|}{$\mathrm{Q}: \mathrm{P}$} \\
\hline & & & & & & & $<2 \mu \mathrm{m}$ & $>2 \mu \mathrm{m}$ \\
\hline $8-1,118-121$ & 409.2 & 3 & 31.2 & & & & & $60: 40$ \\
\hline $8, \mathrm{CC}$ & 417.5 & 2 & 29.4 & & & & & $45: 55$ \\
\hline \multicolumn{9}{|l|}{$9-2,113-120$} \\
\hline 1 & 458.1 & 58 & 15.0 & 75 & $85: 15$ & $36: 64$ & $63: 37$ & $27: 73$ \\
\hline 2 & 459.0 & 68 & 14.7 & 75 & $85: 15$ & $38: 62$ & $81: 19$ & $28: 72$ \\
\hline 3 & 459.9 & 68 & 14.7 & 75 & $84: 16$ & 49:51 & $70: 30$ & $22: 78$ \\
\hline 4 & 460.8 & 69 & 14.3 & 70 & $82: 18$ & $43: 57$ & $71: 29$ & $31: 69$ \\
\hline 5 & 461.7 & 65 & 15.3 & 70 & $81: 19$ & $47: 53$ & $65: 35$ & $31: 69$ \\
\hline 6 & 462.6 & 43 & 19.6 & 65 & $78: 22$ & $66: 34$ & $100: 0$ & $43: 57$ \\
\hline 7 & 463.5 & 26 & 23.2 & 65 & $67: 33$ & $52: 48$ & $100: 0$ & $38: 62$ \\
\hline 8 & 464.4 & 9 & 24.8 & 50 & $63: 37$ & - & $100: 0$ & $98: 2$ \\
\hline
\end{tabular}

Note: $\mathrm{S} / \mathrm{I}=$ Smectite/illite, $17 \AA ; \mathrm{Q}=$ Quartz, $3.34 \AA ; \mathrm{P}=$ Plagioclase, $3.16-3.21 \AA$.

${ }^{a}$ Analyses by T.F. Anderson, Department of Geology, University of Illinois, Urbana, Illinois.

Relative XRD peak intensities of $<2 \mu \mathrm{m}$ fraction

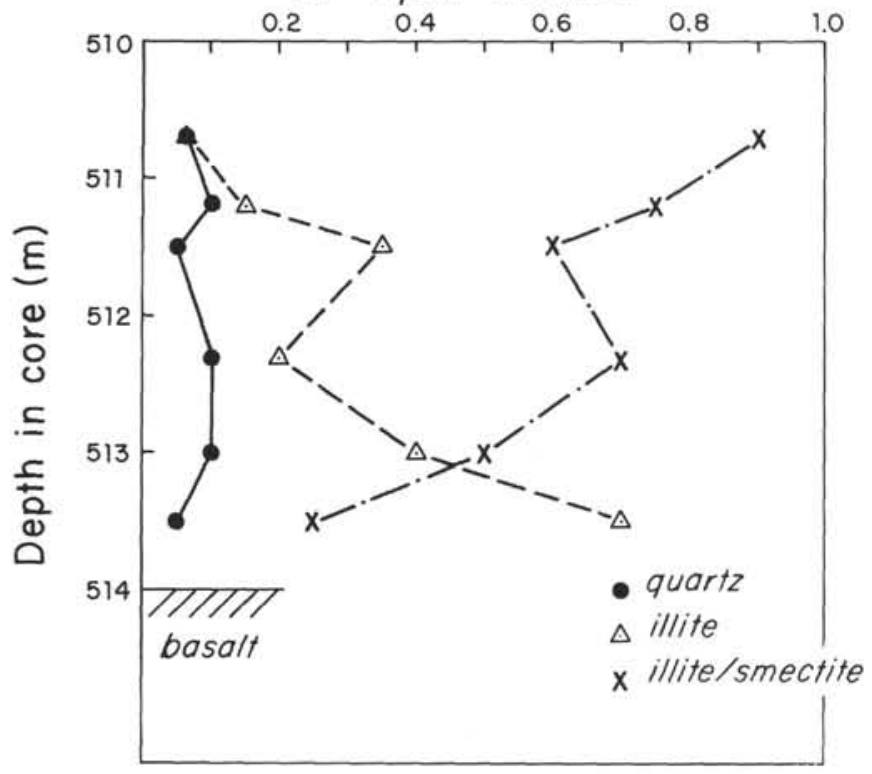

$\%$ smectite layers

in illite/smectite

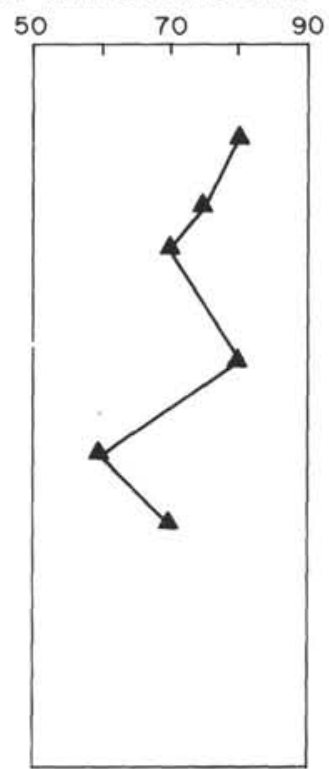

Quartz/plagioclase of $>2 \mu \mathrm{m}$ fraction

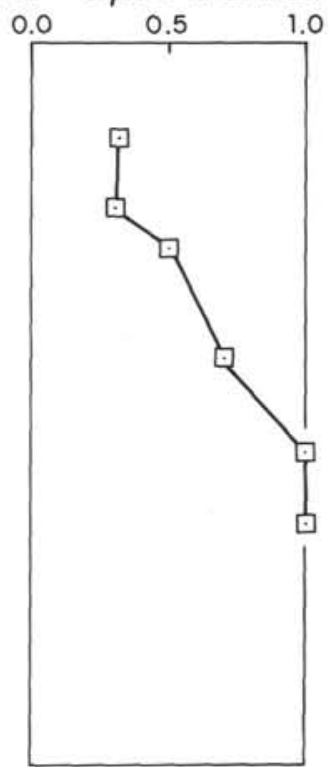

Figure 1. Relative X-ray diffraction peak intensities of the less than and greater than $2 \mu \mathrm{m}$ fractions of the basal sediments,

Site 322, versus depth. The intensity of each peak is normalized to the sum of the 7,10 , and $17 \AA$ peak intensities.

mation of phillipsite. Plate 1, Figure 1 shows the authigenic iron-rich smectite forming on a highly pitted basaltic glass surface. Intimate intergrowth of phillipsite crystals and smectite on a similar basaltic glass surface is shown in Plate 1, Figures 2 and 3. At a further stage the smectite and phillipsite crystals cover most of the basaltic glass surface (Plate 1, Figure 4) and welldeveloped and larger phillipsite crystals are more abundant.

On the basis of the above observations and observed oxygen isotope, $\mathrm{Ca}^{+2}, \mathrm{Mg}^{+2}$, and $\mathrm{K}^{+}$gradients in interstitial waters as a function of depth (Gieskes and Lawrence this volume), the following weathering sequence for basalt of Site 322 is suggested:

(1) At shallow burial depths, basalt, in particular olivine (if present), pyroxene, and basaltic glass will release $\mathrm{Ca}^{+2}, \mathrm{Mg}^{+2}$, and iron. Iron is relatively immobile and will precipitate locally as iron hydroxide. A residual amorphous phase enriched in silica will develop.

(2) Smectite starts to form and consumes the $\mathrm{Mg}^{+2}$ that continuously is released during pyroxene weathering, as well as from interstitial waters (as a result of small changes in $\mathrm{CO}_{2}$ and $p \mathrm{H}$ of interstitial waters?). $\mathrm{Mg}^{+2}$ depletion and $\mathrm{Ca}^{+2}$ enrichment in interstitial waters of basal sediments were observed by Gieskes and Lawrence (this volume). The smectite will also consume iron. The $\mathrm{Fe} / \mathrm{Al}$ ratio of the smectite depends on the chemical composition of the pyroxenes, amount of olivine in basalt, and the extent of plagioclase weathering.

(3) $\mathrm{The} \mathrm{Si} / \mathrm{Al}$ ratio decreases as a result of smectite formation and further plagioclase weathering. Consequently, phillipsite may start to form. Phillipsite formation is most probably responsible for the observed $\mathrm{K}^{+}$ 
depletion in interstitial waters of the basal sediments (Gieskes and Lawrence, this volume). The formation of both smectite and phillipsite is responsible for the small observed $\delta \mathrm{O}^{18}$ depletion in the interstitial waters $(0.1 \% / 00 / 100 \mathrm{~m})$.

\section{Site 323}

Twelve samples from the center of Unit 2 (266-507.5 $\mathrm{m})$, of relatively indurated diatomaceous claystones and chert; two samples with authigenic calcite rhombs from Unit 3 (507.5-638 m) of gray claystone with no biogenous silica; five samples from the lowermost part of Unit $5(666.5-701 \mathrm{~m})$, of yellow-brown zeolitic claystone; and six basalt samples were studied. (No samples were examined from Unit $4, \mathrm{Fe}$ - and nannoclaystone.) Their mineralogy is summarized in Tables $1 \mathrm{~B}$ and 2.

Based on X-ray diffraction and chemical analyses, Drever (this volume) observed a typical terrigenous assemblage above 639 meters, and a predominantly altered volcanic assemblage below 639 meters.

Chemical and oxygen isotope analyses of interstitial waters (Gieskes and Lawrence, this volume) show distinct gradients as a function of depth. The $\mathrm{Mg}^{+2}, \mathrm{~K}^{+}$, silica and $\mathrm{Ca}^{+2}$ curves indicate a sink for $\mathrm{Mg}^{+2}, \mathrm{~K}^{+}$, and silica and a source for $\mathrm{Ca}^{+2}$ at about 450 meters. Porcelanite layers were recovered at this interval. $\mathrm{Mg}^{+2}$ concentration drops to $10 \mathrm{mmoles} / \mathrm{l}$, and $\mathrm{Ca}^{+2}$ shows a marked increase close to the contact of basalt and basal sediments. $\mathrm{K}^{+}$drops to almost zero a few meters above the basalt. $\delta \mathrm{O}^{18}$ values decrease with depth between 0.4 to $0.5^{\circ} / 00 / 100$ meters. All samples described in Tables $1 \mathrm{~B}$ and 2 are from the above depth intervals where either sinks or sources for major elements are indicated.

\section{UNIT 2: SILICEOUS CLAYS AND PORCELANITES}

Only 45 meters of siliceous clays separate the porcelanite layers of Samples 323-8-1, 118-121 cm and $323-8$, CC from Sample 323-9-2, pieces 7 and 8 of Table 2. The $\delta \mathrm{O}^{18}$ values of the upper two samples are significantly higher than the $\delta \mathrm{O}^{18}$ values of pieces 7 and 8 (Anderson and Lawrence, this volume) and Table 2. Based on an average geothermal gradient of $6^{\circ} \mathrm{C} / 100$ meters and the assumption that the upper and lower porcelanite layers formed more or less simultaneously in equilibrium with their present environment, their $\delta \mathrm{O}^{18}$ values should indicate only $2^{\circ}$ to $3^{\circ} \mathrm{C}$ difference in temperature of formation. Based on a fractionation factor of 1.039 between opal-CT or quartz and water at $0^{\circ} \mathrm{C}$, and fig. 3 of Knauth and Epstein (1975), the temperature of formation of the upper porcelanite layers is about $32^{\circ} \mathrm{C}$ and of the lower porcelanite $65^{\circ} \mathrm{C}$. A difference of $33^{\circ} \mathrm{C}$ in the temperature of formation of the two adjacent porcelanites is not probable. Dilution by volcanogenic material and/or hydrothermal activity prior to the deposition of the upper layers could account for the above observed depletion in $\delta \mathrm{O}^{18}$ of the lower porcelanite (Piece 8, Table 2).

Dissolution of biogenous silica provided most of the silica for both the upper and lower porcelanites as shown in Plates 2 and 3 . Table 2 shows that volcanogenic material is much more abundant in the lower siliceous claystones (Pieces 1 to 6) and porcelanites (Pieces 7 and 8 ) than in the upper porcelanites. Volcanogenic material has low $\delta \mathrm{O}^{18}$ values of about +6 to $+10^{\circ} \%$, depending on its degree of alteration. As mentioned already, these impurities could account for the lower observed $\delta \mathrm{O}^{18}$ values of the deeper porcelanite layers.

In addition to detrital volcanic glass and plagioclase, authigenic Al-rich smectite and $\mathrm{K}$-feldspar were identified in the lower siliceous claystones and porcelanite layers, as shown in Plate 3. Opal-CT and quartz are the only authigenic minerals in the upper porcelanite layers.

An assemblage of porcelanite, smectite, K-feldspar, and/or clinoptilolite should not be used as proof of a volcanic origin of such bedded porcelanites.

Volcanic impurities in the lower porcelanite beds affect the cathode-luminescence properties of these porcelanites. Bluish luminescing domains are present in an orange luminescing matrix. The upper porcelanite beds can be easily recognized on the basis of their homogeneous orange cathode luminescence.

Plate 2 shows the dense structure of the upper porcelanite beds, Samples 323-8-1, 118-121 cm and 3238 , CC. A few partially dissolved biogenic silica tests are still recognizable. They are an integral part of the porcelanite, cemented by opal-CT. A reaction series from siliceous clays with volcanogenic impurities to porcelanite (Sample 323-9-2, pieces 1 to 8 ) is shown in Plate 3 . The sequence is as follows:

(1) Biogenic silica partially dissolves, and opal-CT lepispheres precipitate adjacently (Plate 3, Figure 1).

(2) Dissolution of biogenic silica continues. Volcanogenic material, volcanic glass and plagioclase in particular, starts to dissolve (and the $p \mathrm{H}$ and $\mathrm{CO}_{2}$ of interstitial waters will slightly change?). Opal-CT lepispheres continue to precipitate, and aluminum and magnesium-rich smectite forms at the sites of opal-CT precipitation. The two authigenic phases are intergrown (Plate 3, Figures 2 and 3). The smectite is a sink for $\mathrm{Mg}^{+2}$, and the dissolution of plagioclase and a few coccoliths (Plate 3, Figure 4) are a source for the increased $\mathrm{Ca}^{+2}$ in interstitial waters observed by Gieskes and Lawrence (this volume).

(3) The rapid decrease in porosity does not allow the continuous precipitation of opal-CT as lepispheres. Instead, a massive texture develops (Plate 3, Figures 3 and 6). Smectite continues to form slowly.

(4) The $\mathrm{Si} / \mathrm{Al}$ ratio available for the formation of authigenic silicates changes. It can either increase or decrease. It will increase if the amount of available volcanogenic material is small. Clinoptilolite with an $\mathrm{Si} / \mathrm{Al}$ ratio of greater than 4.5 will form. The assemblage of opal-CT, smectite, and clinoptilolite is widespread in deep-sea porcelanites. The $\mathrm{Si} / \mathrm{Al}$ ratio will decrease if the amount of available volcanogenic material, plagioclase in particular, is high. After most of the biogenic silica has dissolved, the volcanogenic material will weather at increased rates. Authigenic silicates such as illite or $\mathrm{K}$-feldspar or albite, with lower $\mathrm{Si} / \mathrm{Al}$ ratios than the ratio in smectite will form. Authigenic Kfeldspar crystals are shown in Plate 3, Figure 7. The Kfeldspar is a sink for $\mathrm{K}^{+}$. 


\section{UNIT 3: GRAY CLAYSTONE \\ WITH NO BIOGENIC SILICA}

Calcite rhombs are the only authigenic phase observed in the two samples studied (Table 1B). Their $\delta \mathrm{O}^{18}$ and $\delta \mathrm{C}^{13}$ values are discussed in Anderson and Lawrence (this volume).

\section{UNIT 5: YELLOW-BROWN ZEOLITIC CLAYSTONE}

Samples from the lowermost $2 \mathrm{~cm}$ of this unit were examined. (No samples were examined from the overlying Unit 4.) Authigenic smectite and clinoptilolite predominate. The effect of detrital components on the $\delta \mathrm{O}^{18}$ values (analyzed by J.R. Lawrence) of the $>2 \mu \mathrm{m}$ fraction is shown in Table 1B. The $\delta \mathrm{O}^{18}$ values of the $>2$ $\mu \mathrm{m}$ fraction are lower by 2 to $3 \%$ relative to the clay size fraction.

$\mathrm{X}$-ray energy-dispersive analysis of the clinoptilolite and coexisting smectite gave the following results:

$$
\begin{array}{cc}
\text { Clinoptilolite } & \text { Smectite } \\
\mathrm{Si} / \mathrm{Al} \simeq 4.7 & \mathrm{Fe} / \mathrm{Al} \simeq 0.5 \\
\mathrm{~K}>>\mathrm{Ca}>\mathrm{Na} & \mathrm{Al}>\mathrm{Fe}>\mathrm{Mg}
\end{array}
$$

The euhedral crystals of clinoptilolite and the authigenic smectite of Sample 323-18-4, 107-111 cm are shown in Plate 4, Figures 2 and 3. The smectite associated with clinoptilolite has a much lower $\mathrm{Fe} / \mathrm{Al}$ ratio of $\sim 0.5$ than the smectite associated with phillipsite, with a ratio of $\sim 1.7$. Furthermore, mainly colorless (more siliceous) glass shards were observed in the clinoptilolite-rich samples, while brownish glass shards and palagonite were observed in the phillipsite-rich sample of Site 322. Thus, smectites chemically reflect the composition of their precursor(s).

The smectite of Sample 323-18-6, 73-83 cm was identified by Drever (this volume) as saponite. Bass et al. (1973) suggested that saponite is a weathering product of olivine.

\section{BASALT}

The aphyric aphanitic basalt with no evidence of glassy zones, palagonite, or hyaloclastite, and composition of mid-oceanic ridge tholeiite basalt (Vennum, this volume) is altered to celadonite, smectite, calcite, and goethite. Olivine crystals are rare. Pyroxene crystals are highly altered to celadonite. Plagioclase is only partially replaced by celadonite. Celadonite is also concentrated in veins with goethite and calcite. Textural relations indicate that some of the goethite preceded the celadonite. Calcite was the last phase to precipitate in the veins.

The following is a semiquantitative ${ }^{2}$ microprobe analysis of a celadonite vein Sample 323-19-3, 90-92 cm, piece 10:

$\begin{array}{llr} & & \text { wt\% } \\ \text { Total iron as } & \mathrm{SiO}_{2} & 52.2 \\ & \mathrm{Al}_{2} \mathrm{O}_{3} & 5.5 \\ & \mathrm{Fe}_{2} \mathrm{O}_{3} & 15.8\end{array}$

\footnotetext{
${ }^{2}$ In order to preserve the celadonite vein, the thin section was not polished as well as required for a quantitative analysis.
}

$\begin{array}{lr}\mathrm{MgO} & 6.9 \\ \mathrm{~K}_{2} \mathrm{O} & 9.3 \\ \mathrm{Na}_{2} \mathrm{O} & <0.5\end{array}$

Celadonite as a submarine alteration product of basalt was described by, for example, Bass et al. (1973) from the Central Pacific, Leg 17, and by Kempe (1974) from the Indian Ocean, Leg 26. The microprobe analysis given by Kempe (Table 4) is similar to the above analysis. Foster (1969) and Weaver and Pollard (1973) discussed the chemical differences between celadonite and glauconite: celadonites are higher in magnesium (with a median of $6.12 \% \mathrm{MgO}$ ) than glauconites (with a median of $3.58 \% \mathrm{MgO}$ ). Celadonites also have less tetrahedral aluminum, but a considerable overlap exists. Celadonite must form prior to the completion of iron oxidation.

Does submarine weathering of tholeiite basalt induce a local high magnesium environment and the formation of celadonite? Or is the celadonite a product of hydrothermal alteration? The $\delta \mathrm{O}$ of the above analyzed celadonite is $+21.4 \pm 1.0$ (analyzed by J.R. Lawrence). The value suggests a temperature of greater than $30^{\circ} \mathrm{C}$, assuming equilibrium with water of $0 \%$ and using Yeh's (1974) fractionation factor between illite and water. It is possible that the same hydrothermal solutions are responsible for the enrichment zone in transition elements and $\mathrm{Sr}$ at 30 to 74 meters above the basalts, as described by Drever (this volume). The smectite from a clay pod, Sample 323-19-1, 90-95 cm, piece 1, above the celadonite zone, is highly crystallized, unlike many diagenetic smectites, and might also be a product

\begin{tabular}{|c|c|}
\hline Site 322 & Site 323 \\
\hline $\begin{array}{l}\text { Amorphous material is } \\
\text { present. } \\
\text { Smectite is either } \\
\text { very fine grained or } \\
\text { has a poor crystallinity. }\end{array}$ & $\begin{array}{l}\text { No amorphous material is } \\
\text { observed. } \\
\text { Smectite is well } \\
\text { crystallized. }\end{array}$ \\
\hline $\begin{array}{l}\text { No } 10 \AA \text { phase has been } \\
\text { observed. } \\
\text { Calcite veins are not } \\
\text { common. }\end{array}$ & $\begin{array}{l}\text { Celadonite in veins and as } \\
\text { replacement of pyroxenes. } \\
\text { Calcite veins are } \\
\text { abundant. }\end{array}$ \\
\hline
\end{tabular}
of hydrothermal reactions. The smectite probably formed after the celadonite.

As mentioned already, the weathering products of Site 322 basalt are different from the weathering products of Site 323 basalt. The major differences are:

The formation of celadonite and smectite is responsible for the $\mathrm{Mg}^{+2}$ and $\mathrm{K}^{+}$depletion in interstitial waters, and the weathering of pyroxene and to a lesser extent of plagioclase is responsible for the observed increase in $\mathrm{Ca}^{+2}$.

A reaction for the formation of the observed assemblage celadonite, goethite, and calcite is suggested:

$$
\begin{aligned}
& \begin{array}{cc}
\text { Augite }^{3} & \text { + } \\
\text { Xlagioclase } & { }^{3} \\
\left.\mathrm{Ca}_{43} \mathrm{Mg}_{30} \mathrm{Fe}_{27}\right) \mathrm{SiO}_{3} & \text { Y. }\left(\mathrm{An}_{55-70}\right)
\end{array} \\
& +\mathrm{H}_{2} \mathrm{CO}_{3}+\mathrm{K}^{+4}+\mathrm{Mg}^{+25} \longrightarrow
\end{aligned}
$$

\footnotetext{
${ }^{3}$ Composition given by W. Vennum (this volume) for Sites 322 and 323.

${ }^{4} \mathrm{~K}^{+}$from seawater.
} 


$$
\begin{aligned}
& \begin{array}{c}
\text { Celadonite }{ }^{6} \\
\left(\mathrm{~K}_{0.64}{ }^{\mathrm{Na}}{ }_{0.13} \mathrm{Ca}_{0.06}\right)\left(\mathrm{Al}_{0.49} \mathrm{Fe}_{0.72}^{+3} \mathrm{Fe}_{0.21}^{+2} \mathrm{Mg}_{0.63}\right)
\end{array} \\
& \left(\mathrm{Al}_{0.19} \mathrm{Si}_{3.81}\right) \mathrm{O}_{10}(\mathrm{OH})_{2} \\
& +\mathrm{CaCO}_{3}+\text { Goethite }^{5}+\mathrm{Ca}^{+2}+\mathrm{Na}^{+}+\mathrm{Si}(\mathrm{OH})_{4}{ }^{7} \\
& \alpha-\mathrm{FeO}(\mathrm{OH})
\end{aligned}
$$

$\mathrm{X}>>\mathrm{Y}$, because at Site 323 augite is highly altered, plagioclase only slightly.

\section{SUMMARY AND CONCLUSIONS}

1. Diagenetic reactions at Site 323 are more numerous and extensive than at Site 322 .

2. Chemical gradients in interstitial waters indicate the depth intervals for sinks and sources of major and minor elements.

3. The $\mathrm{Fe} / \mathrm{Al}$ ratio of authigenic smectite associated with phillipsite is higher than the $\mathrm{Fe} / \mathrm{Al}$ ratio of authigenic smectite associated with clinoptilolite. The chemistry of both smectites reflects the chemical composition of their precursor(s).

4. The diagenetic products of basalt weathering at Site 322 are: amorphous material, smectite, and phillipsite. However, at Site 323 the diagenetic products are: smectite, celadonite, goethite, and calcite. These differences probably are due to a combination of the following factors: (a) The oceanic basement at Site 323 is much older. (b) Site 323 has a thicker sedimentary sequence; 701 meters at Site 323 and 514 meters at site 322 . (c) The average sedimentation rate is higher at Site 322 ( 5 to $3 \mathrm{~cm} / 1000 \mathrm{yr}$ ) than at Site $323(5$ to $1.5 \mathrm{~cm} / 1000$ yr). (d) Hydrothermal activity might have affected the observed assemblage at Site 323 .

5. Dissolution of biogenic silica provided most of the silica for the porcelanite beds of Site 323.

6. The formation and chemical composition of additional diagenetic silicate phases within porcelanite

\footnotetext{
${ }^{5}$ The formation of goethite depends on the amount of $\mathrm{Mg}^{2+}$ uptake from seawater. The $\mathrm{Fe} / \mathrm{Mg}$ ratio in augite is smaller than in celadonite. Goethite is rather abundant in Samples 323-19-1, piece 7, and 323-19-3, piece 10, but much less so in the shallower Sample 323$18-6,73-83 \mathrm{~cm}$.

'Average formula based on 15 analyses by Weaver and Pollard (1973).

'Depends on numerous factors.
}

beds depend on the presence and abundance of volcanogenic material. The volcanogenic impurities may affect the $\delta \mathrm{O}^{18}$ values of porcelanite.

\section{ACKNOWLEDGMENTS}

I thank Dr. Jim Lawrence for several oxygen isotope analyses, and Dr. Joris Gieskes for the manganese analysis of a calcite vein. The research was supported by a grant from the International Nickel Company, Inc. to the Institute of Marine Resources, Scripps Institution of Oceanography.

\section{REFERENCES}

Bass, N.M., Moberly, R., Rhodes, J.M., Shih Chi-yu, and Church, S.E., 1973. Volcanic rocks cored in the Central Pacific, Leg 17, Deep Sea Drilling Project. In Winterer, E.L., Ewing, J.I., et al., Initial Reports of the Deep Sea Drilling Project, Volume 17: Washington (U.S. Government Printing Office), p. 429-503.

Drever, J.I., 1973. The preparation of oriented clay mineral specimens for X-ray diffraction analysis by a filtermembrane peel technique: Am. Mineral., v. 58, p. 553-554.

Foster, M.D., 1969. Studies of celadonite and glauconite: U.S. Geol. Surv. Prof. Paper614-F.

Kempe, D.R.C., 1974. The petrology of basalts, Leg 26, Deep Sea Drilling Project. In Davies, T.A., Luyendeyh, B., et al., Initial Reports of the Deep Sea Drilling Project, Volume 26: Washington (U.S. Government Printing Office), p. 465503.

Knauth, L.P. and Epstein, S., 1975. Hydrogen and oxygen isotope ratios in silica from JOIDES Deep Sea Project: Earth Planet. Sci. Lett., v. 25, p. 1-10.

Lawrence, J.R., Gieskes, J.M., and Broecker, W.S., 1975. Oxygen isotope and cation composition of DSDP pore waters and the alteration of Layer II basalts: Earth Planet. Sci. Lett., v. 27, p. 1-11.

Reynolds, R.C. and Hower, J., 1970. The nature of interlayering in mixed-layer illite/montmorillonites: Clays Clay Mineral., v. 18 , p. 25-36.

Sheppard, R.A., Gude, A.J., and Griffin, J.J., 1970. Chemical composition and physical properties of phillipsite from the Pacific and Indian oceans: Am. Mineral., v. 55, p. 20532062.

Towe, K.M., 1974. Quantitative clay petrology: the trees but not the forest: Clays Clay Mineral., v. 22, p. 375-378.

Weaver, C.E. and Pollard, L.D., 1973. The chemistry of clays. Developments in sedimentology 15: New York (Elsevier).

Yeh, H.W., 1974. Oxygen isotope studies of ocean sediments during sedimentation and burial diagenesis: Ph.D. Thesis, Case Western Reserve University. 
PLATE 1

Scanning electron microscope photographs of authigenic smectite and phillipsite on an etched and pitted basaltic glass surface. White lines in lower left represent $2.5 \mu \mathrm{m}$ for Figures 1 and 2, $1 \mu \mathrm{m}$ for Figure 3, and $6 \mu \mathrm{m}$ for Figure 4 .

Figure 1 Stage 1: authigenic smectite forms preferentially either at or from the pits.

Figures 2,3 Stage 2: intimate intergrowth of smectite and euhedral phillipsite.

Figure 4 Stage 3: the basaltic glass surface is almost completely covered by smectite and well-developed euhedral phillipsite crystals. 


\section{PLATE 1}
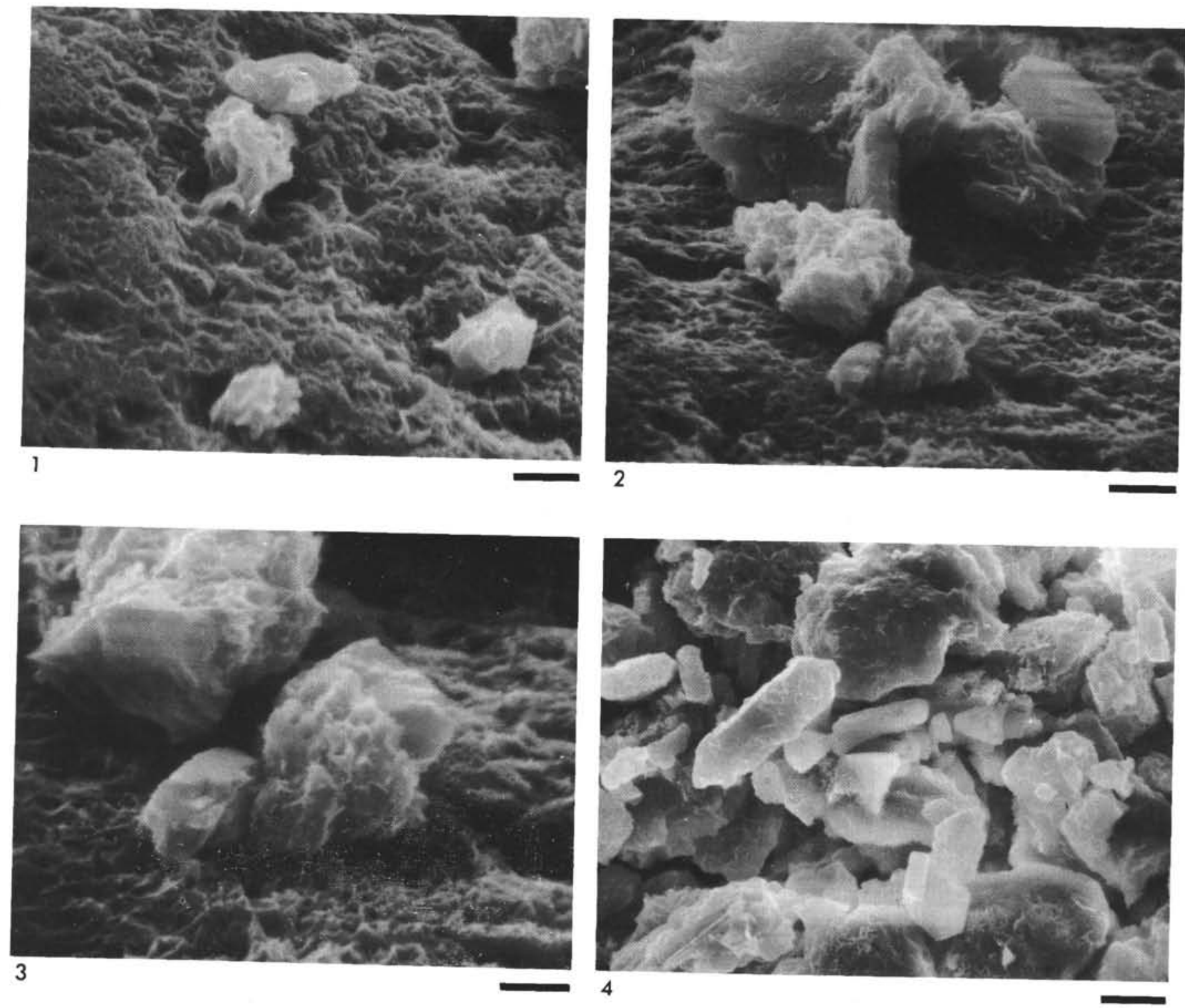


\section{PLATE 2}

Scanning electron microscope photographs of upper porcelanite beds, Site 322 (see Table 2). White lines in lower right represent 6 $\mu \mathrm{m}$ for Figure 1 and $1.4 \mu \mathrm{m}$ for Figures 2 and 3.

Figures 1,2 A few highly dissolved biogenic silica tests are still recognizable in the dense opal-CT matrix, Sample $323-8-1,118-121 \mathrm{~cm}$.

Figure 3 Dense porcelanite. Sample 323-8, CC. 
PLATE 2
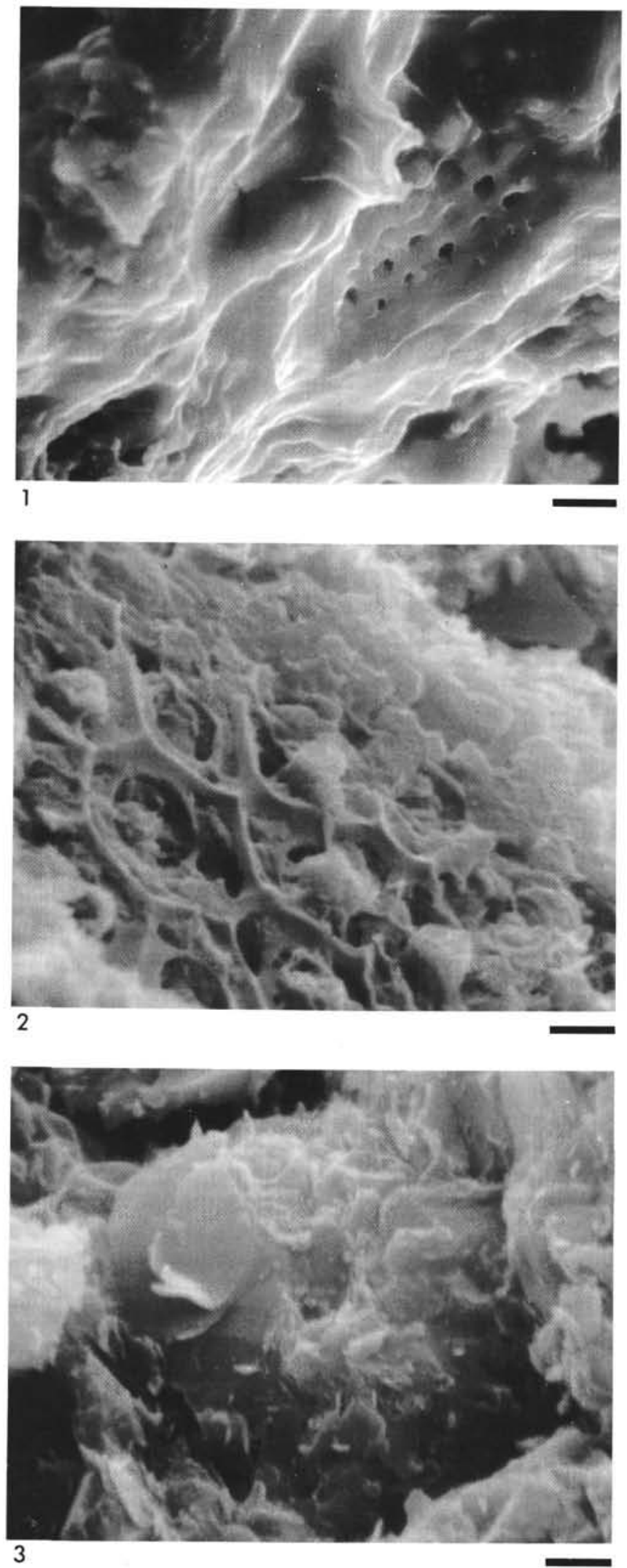


\section{PLATE 3}

Scanning electron microscope photographs of biogenic silica dissolution and authigenic opal-CT lepispheres, smectite, and Kfeldspar formation, in the siliceous clays and lower porcelanite beds of Samples 322-9-2, 113-120 cm, Table 2. White lines in lower right represent $2 \mu \mathrm{m}$ for Figures 1 and 7, $1.6 \mu \mathrm{m}$ for Figures 2 and $3,3 \mu \mathrm{m}$ for Figure 4, $0.7 \mu \mathrm{m}$ for Figure 5, and $1.2 \mu \mathrm{m}$ for Figure 6.

Figure Opal-CT lepispheres attached to or adjacent to a partially dissolved siliceous test, sample \#1 (Table 2).

Figures 2, 3 Intimate intergrowth of opal-CT lepispheres and smectite, at the site of an extensively dissolved siliceous test, sample \#3 (Table 2).

Figure 4 Highly dissolved coccolith, sample \#3 (Table 2).

Figure $5 \quad$ Porcelanite with smectite. Opal-CT lepispheres are no more present, and only very few highly dissolved siliceous tests are still present, sample \#5 (Table 2).

Figure $6 \quad$ Authigenic K-feldspar crystals and smectite on a porcelanite surface, sample \#6 (Table 2).

Figure 7 A very dense porcelanite surface with an authigenic K-feldspar crystal in lower center, sample \#7 (Table 2). 
PLATE 3
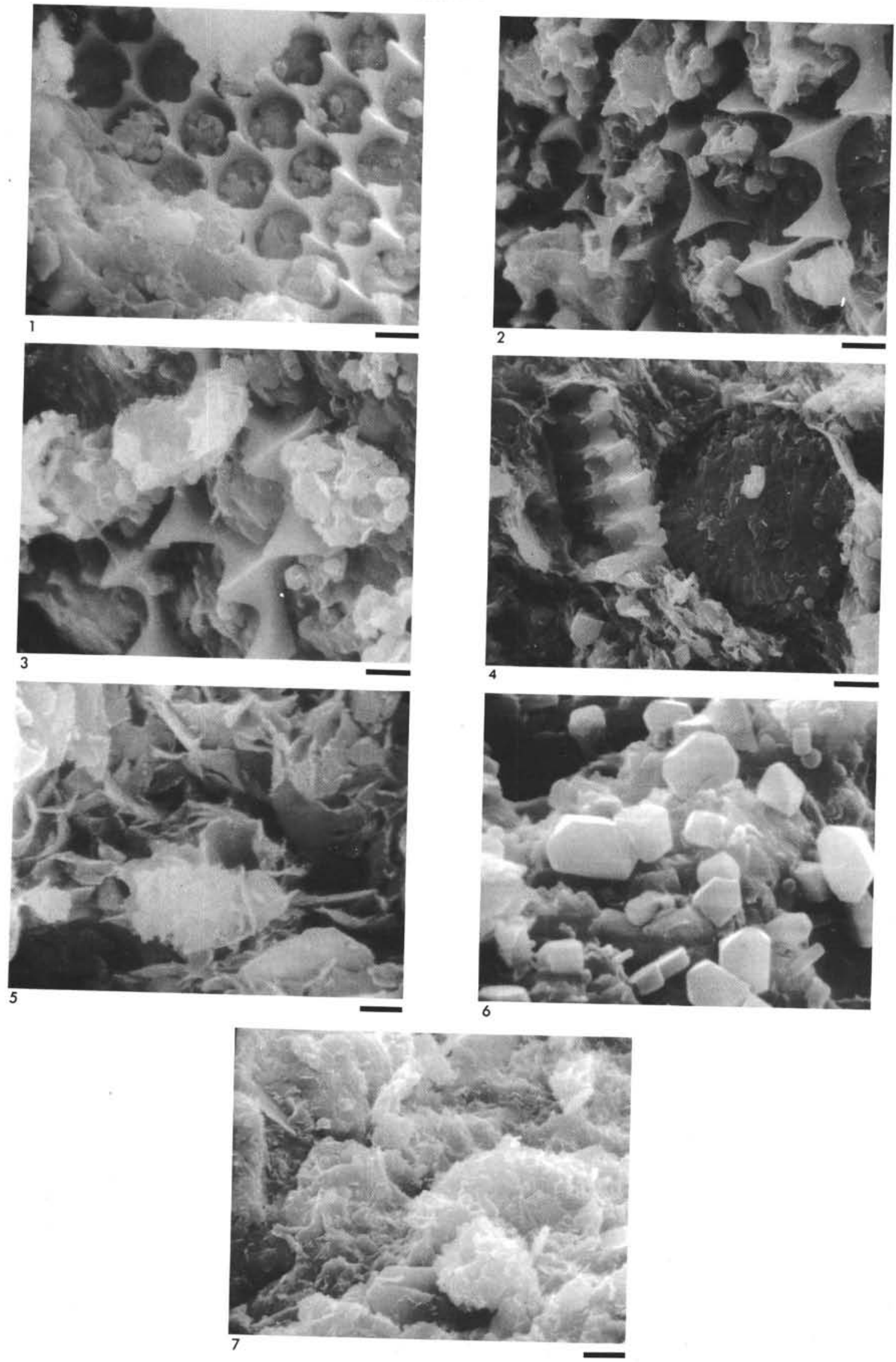
PLATE 4

Scanning electron microscope photographs of authigenic smectite and clinoptilolite, Sample 323-18-4, 107-111 cm. White lines in lower right of Figure 1 represent $2 \mu \mathrm{m}$, and of Figure $25 \mu \mathrm{m}$. 

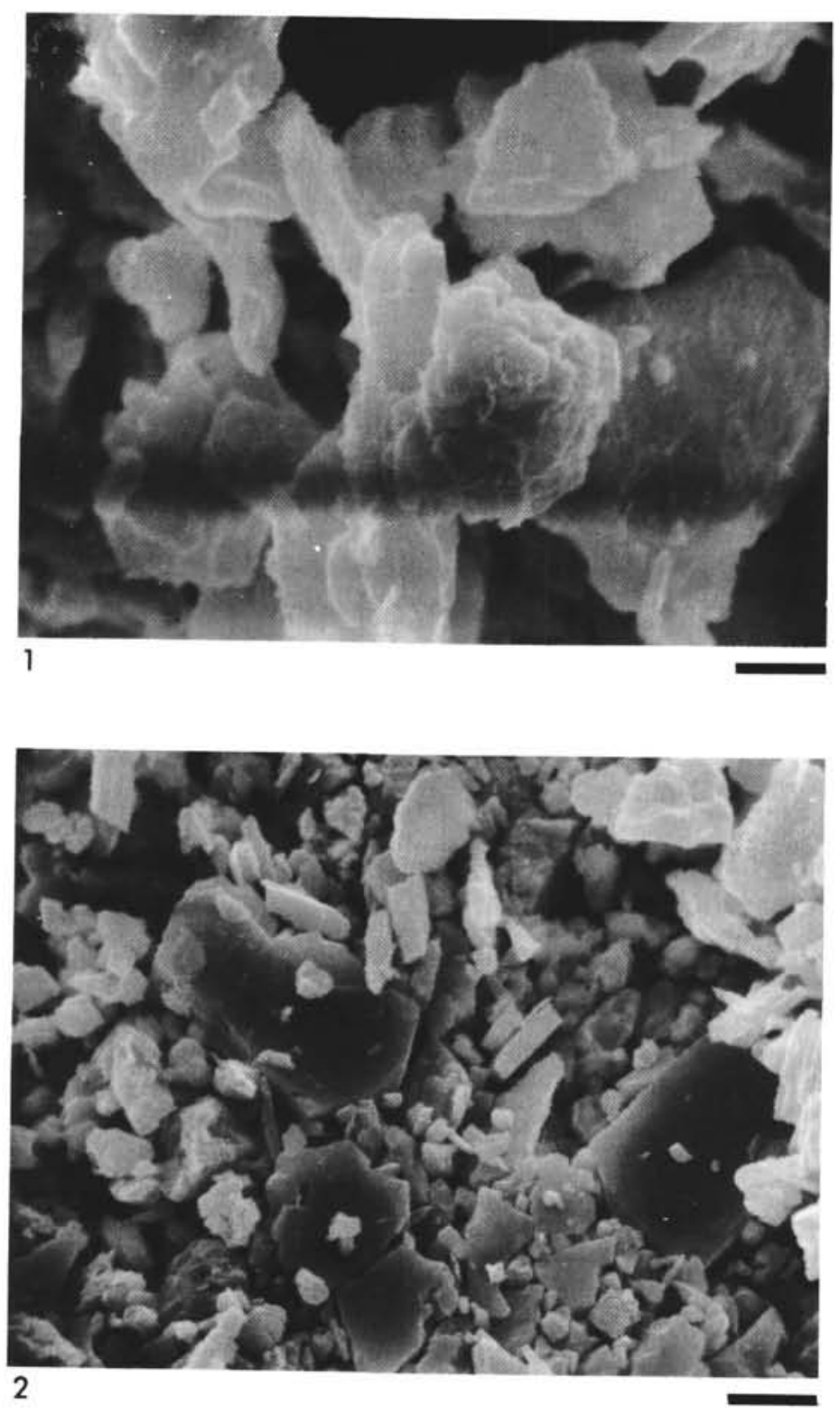